\title{
Notes for a didactic model of critical geography. Analysis and evaluation of a classroom experience with university students from Galicia (Spain)
}

\author{
Xosé Carlos Macía Arce ${ }^{A *}$, Francisco Rodríguez Lestegás ${ }^{\mathrm{B}}$, Francisco Xosé Armas Quintác \\ Received: May 2, 2017 | Revised: July14, 2017 | Accepted: July 19, 2017 \\ DOI: $10.5937 / G e o P a n 1703124 M$
}

\begin{abstract}
This article presents a didactic model of critical geography, based on instruction recommendations for the teaching and learning of geography and social sciences. This is all with a very clear idea: to depart from a descriptive and reflective geography and move to an active and critical geography. Geography in which students participate in the construction of knowledge and increase their ability to reflect on geographical issues. The proposed didactic model drives active and critical geography in the classrooms. It starts with the analysis of territorial problems in Europe and makes them the object of research and reflection. The idea is not to dictate geography in classrooms but to introduce methodologies, resources and sources to carry out geographic research with students. With this idea in mind, the second part of the article examines the value of our didactic model through the analysis of fifteen research projects on European natural spaces carried out in the academic years of 2014-2015 and 2015-2016 with 74 university students in training to be geography teachers in secondary education. The results show that the students' didactic expectations grow when given geographic research to do as teaching practice.
\end{abstract}

Keywords: Reflective and critical geography; teaching model; classroom experience; ITC resources; thematic cartography; European geography

\section{Introduction}

Descriptive geography has always had a strong presence in secondary school classrooms. Locating rivers on a physical map, recognising cities on a pointmap or memorising the geographic economy of any region are part of the usual teacher approach. However, geography is much more. Geography can undoubtedly provide a much deeper and, above all, a much more applied knowledge when identifying and solving realproblems in specific territories.
Students in the twenty-first century cannot be limited to merely receiving transmissive classes with inconsequential information which they will later be forced to memorise and pass an assessment on. Great encyclopaedic knowledge is no more than an inconsequential hindrance from the past in the Information Society, so mentioning all the tributaries of the Duero River from east to west, or from north to south, or the most important mountain ranges in Europe only require simple memorisation of content exercises which, basically, lead nowhere.

\footnotetext{
A Area of Teaching Social Sciences, Department of Applied Didactics, Faculty of Education Sciences, University of Santiago de Compostela, Avda. Xoán XXIII s/n, Campus Norte, 15782 Santiago de Compostela (Spain); carlos.macia@usc.es

B Area of Teaching Social Sciences, Department of Applied Didactics, Faculty of Teacher Training, University of Santiago de Compostela, Avda. Ramón Ferreiro s/n, Campus de Lugo, 27002 Lugo (Spain); f.lestegas@usc.es

c Area of Teaching Social Sciences, Department of Applied Didactics, Faculty of Teacher Training, University of Santiago de Compostela, Avda. Ramón Ferreiro s/n, Campus de Lugo, 27002 Lugo (Spain); francisco.armas@usc.es

* Corresponding author: Xosé Carlos Macía Arce, e-mail: carlos.macia@usc.es
} 
Today students require much more and no longer conform to the decadeold teaching model of regional geography taught in Spain (Luis, 1985). Society today accesses contents in an instant so it is no longer necessary to learn geography by memorising a long list of contents. A simple query on a mobile or a tablet provides access to all the geographic information required at anytime and anywhere, therefore previously understood knowledge can no longer have the same value. Obviously, this does not mean that the new generations can dispense with memorising any kind of geographical knowledge just for the simple fact of having it all on a mobile. It would be absolute nonsense to think that way, especially as minimal descriptive geography will always be necessary to approach a specific territorial reality. What is required is a geography that, at least, allows for an organised articulation and understanding of the basic structures that make up the construction of territories.

In this article, beyond this initial geography, a didactic model that focuses on active, reflexive and critical geography is presented. This model is based on students' ability to interpret and reflect on the spatial realities of any territory, starting from the location, selection and analysis of geographic contents. In other words, this model allows students to start "new school geography" by breaking away from descriptive geography and providing subsequent entry into geographic research at school. The model's objective is for students to associate the subject of geography with a useful and necessary discipline that helps them to locate, understand and respond to territorial problems (Macía, et al., 2015)

Furthermore, this paper also evaluates a teaching model through a classroom experience at the University of Santiago de Compostela (Galicia, Spain) with university students in training to be geography and social science secondary school teachers. The results of the experience has allowed for reflection on the true significance of active and critical geography in the classroom.

\section{Objectives}

The research's main objective was to reflect on the value of a proposed teaching model that will work on geographic contents in secondary education, using university students in training to be geography teachers. Other more specific objectives, but directly related to the main objective of the research, are the following:

- To place value on the advantages offered by the Information Society in the form of tools, resources, contents and geographical sources available on the Internet.
- To recommend the presence of thematic cartography as an essential resource in geography work.

- To present the results of a classroom experience with university students in training to be geography teachers in secondary education through the analysis of fifteen research projects on natural spaces in Europe. These projects were carried out during the academic years of 2014-2015 and 2015-2016.

\section{Teaching methodology}

This teaching model recommends active and critical geography in secondary school education, starting from the analysis of territorial problems that are the object of interpretation and reflection. To carry out this type of geography it is recommendable to use ICT and thematic mapping as strategic resources when doing and presenting geographical research.

The idea has been designed to work with didactic contents related to the human and economic geography of Europe. These contents are attractive, highly present in the media and are part of the official Galician secondary education curricula for the subjects of Geography and History (first, second and third compulsory secondary education) and Geography (higher secondary-education course).

Regarding the tools, resources and sources available on the Internet, our proposal recommends:

- Google Earth, Google Maps and Street View.

- National and local aerial photography from the 1956 American flightand from the 1982 national flight in Spain.

- Geographic Information Systems (GIS) for the Galician landscape.

- Online statistical sources at European, national and local level: Statistical Office of the European Union (Eurostat), National Institute of Statistics of Spain (INE-E), National Institute of Statistics of Portugal (INE-P) and Galician Institute of Statistics (IGE), among others.

- Main free picture banks on the Internet: Google Photos, Morguefile, SXC.hu, Creative Commons, Open Photo, Photo Rack, Stock Vault, Public Domain Photos, Pixabay and Freepik.

Thematic mapping is the second of the strategic tools included in this methodological proposal. Interpretation of the territory through using maps of choropleths, chorochromatic, points, flows or diagrams is crucial to understand the spatial dynamics and their location. The firm belief is that any geographic exercise that is not from cartography loses value and, above all, capacity for spatial representation.

To work on European geography, specialised thematic cartography ona continental level (differentiat- 
ing between macro-regions, regions and smaller entities in the form of provinces, departments, counties, districts or similar) and a regional choice of the local reality, in this case Galicia ${ }^{1}$, as an example of a European region is proposed. Thus, the main cartographic sources recommended in this proposal to work on the geography of Europe are Eurostat, ESPON and the Atlas of the Information Society in Galicia (Armas, Macía, 2014).

Eurostat is the statistical office of the European Union. Its objective is to provide statistical data on Europe and allow comparisons to be made, not only between states, but also between the grouping of regions (NUTS1), regions (NUTS2), provinces or similar $\left(\mathrm{NUTS}_{3}\right)$ and urban areas (LUZ).The statistical databases are organised by topic and offer regional information, population and social conditions, economy and finance, agriculture and fisheries, industry, trade

\section{GDP per capita, 2009}
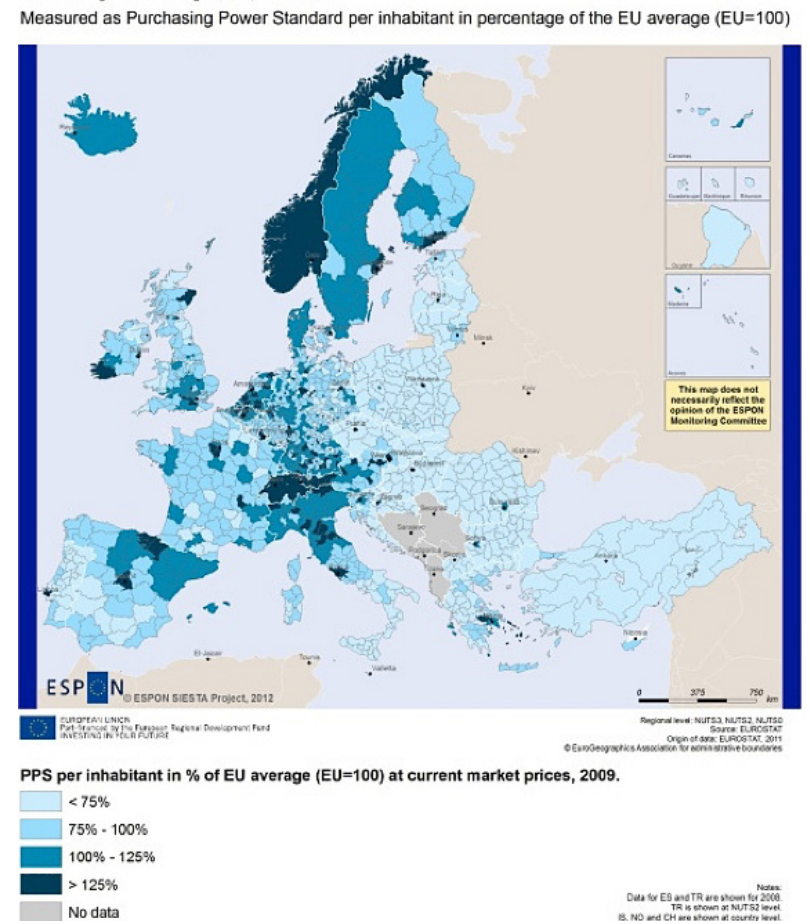

bines base maps with indicators and a statistical index (Macía, 2013).

ESPON is the European Observation Network for Territorial Development and Cohesionfinanced by the European Regional Development Fund. Its aims are to provide the European Commission with an analysis of structures, trends, impacts and territorial perspectives, as well as intelligent and comparable proposals between European regions and cities. The Internet allows access to 25 applied research projects, displaying extremely interesting information in extensive reports which is enriched by the presence of regional maps. These projects analyse Europe's territorial evidence in relation to energy, climate change, economic crisis, poverty, innovation, rural development, transport, cities, etc. (Macía, 2013).

Within the ESPON initiative, the SIESTA project (Spatial Indicators for Europe 2020 Strategy Territo-

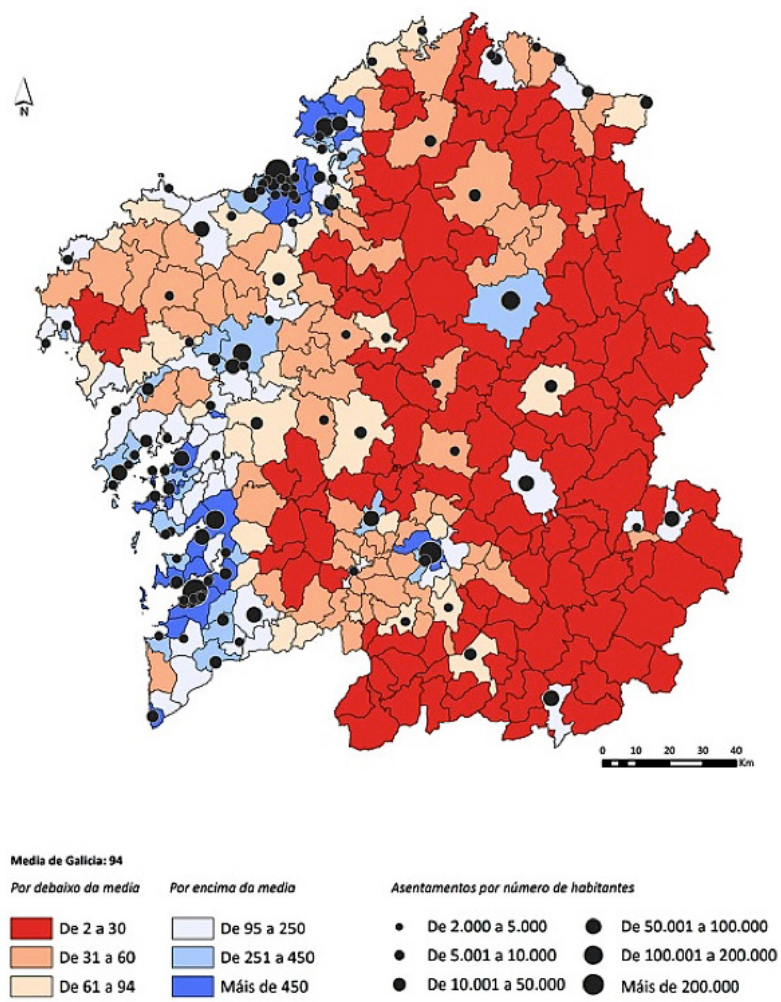

Figure 1. Maps of SIESTA project (left) - Atlas of Galicia for the Information Society (right) Source: ESPON, 2013; Armas, Macía, 2014

and services, environment and energy, science and technology, transport and international trade. This information is presented in tables and graphs, and it is also complemented by an interactive atlas that com-

With Galicia we refer to the Spanish region located in the northwest of the Iberian Peninsula. Please do not confuse it with Galitzia or Galicja, other European regions with territorial presence in Poland (Malopolskie and Podkarpackie voivodships) and Ukraine (oblasts of Lviv, Ternopil, Zakarpattia and Ivano-Frankivsk). rial Analysis) is the most outstanding proposal for working on the regional geography of Europe through an atlas, with more than 70 maps that introduce the territorial dimension of the Europe 2020 strategy (see Figure 1, Lois, et al., 2013, ESPON, 2013).

The Atlas of Galicia for the Information Society (Armas, Macía, 2014) offers 300 thematic maps on the region's social, economic and technological reality and works with statistical information provided by the IGE (see Figure 1). The representations are made 
through point maps, choropleths and chorochromatic at municipal scale, at county level and in regional groupings respecting the provincial boundaries. This solution is ideal because one can appreciate the structure of Galician space in official administrative political territories (313 municipalities), with no recognised legal status ( 53 counties) and in territorial units for statistical purposes (2o county groupings). In addition, all the maps incorporate points with the main population settlements in Galicia, a formula suitable for working on population dynamics.There are such interesting aspects as the concentration of populations in the peri-urban areas of the main cities, the conformation of new axes or corridors, and the importance of the county headlands, which are highly visible aspects in thematic cartography and which help towards understanding regional European realities (Macía, et al., 2016, 2016b).

\section{Classroom research carried out with university students training to be geography secondary school teachers}

Having presented this methodological proposal, the next step in the construction of this research was to implement it by working with 74 university students who are training to be geography and social science secondary school teachers. Specifically, the work was carried out with students from the University of Santiago de Compostela (Galicia) enrolled in a Master's lack of interest aroused some curiosity about putting the didactic proposal into practice in the classroom. A clear intention was to drive this group's evolution towards active and critical geography ${ }^{2}$. To do this we proposed research with this group, and with a group of students from a later course (academic year 20152016). The idea was to discover the living conditions in protected natural spaces of Europe by way of biosphere reserves. With the exception of the Área de Allariz, the research specifically focused on the biosphere reserves in Galicia; the reserve on the Río Eo bordering the Asturian territory (Spain), in Gerês (Portugal) as part of the Gerês-Xurés transboundary park and, finally, in the Valle de Omañay Luna in the province of León (Spain, see Table 1).

To do classroom research, there was a commitment to cooperative and supportive work in student groups of four or five students. In the proposal, teamwork was fundamental because we had tremendous interest in understanding the group dynamics when doing geography. It is important to make clear that personal relationships within the working groups were highly satisfactory. Among other benefits, peer relationships were promoted through the exchange of ideas and theoretical and ideological positions, new approaches and ways of analysing geographical realities were presented, and many questions related to the territory were discussed.

All the assignments presented ordered and coherent structures in a standard geography investigation.

Table 1. Biosphere reserves researched by students from the University of Santiago de Compostela (Galicia, Spain) during the academic years 2014-2015 and 2015-2016

\begin{tabular}{|l|l|l|l|}
\hline Biosphere reserves & Province/District & Region & State \\
\hline As Mariñas Coruñesas e Terras do Mandeo & A Coruña & Galicia & Spain \\
\hline $\begin{array}{l}\text { Os Ancares Lucenses e Montes de Navia, } \\
\text { Cervantes e Becerreá }\end{array}$ & Lugo & Galicia & Spain \\
\hline Río Eo, Oscos e Terras de Bourón & Lugo & Galicia & Spain \\
\hline Terras do Miño & Lugo & Galicia & Spain \\
\hline Xurés & Ourense & Galicia & Spain \\
\hline Río Eo, Oscos eTerras de Bourón & & Asturias & Spain \\
\hline Valle de Omaña y Luna & León & Castile and León & Spain \\
\hline Gerês & Viana do Castelo, Braga and Vila Real & North & Portugal \\
\hline
\end{tabular}

Degree for the Teaching of Compulsory Secondary Education and High School Teaching, Vocational Training and Language Teaching,specialising in Social Sciences and Humanities, during the academic years of 2014-2015 and 2015-2016.

An initial group (academic year 2014-2015) associated the protected natural areas of Europe with outstanding landscape and places with a high quality of life.It was noted that the opinions of this group were based on descriptive geography, and that the general
2 With this group, firstly an associated word test was carried out (Gil, 1994; Liu, 2005) on natural spaces, specifically through the question "quote ten words that relate to natural spaces in Europe". As a result of the application of this test a total of 199 words associated with the protected natural spaces of Europe were registered, but only four of these words (fire on two occasions, mass use and alteration) contributed to a critical or negative approach towards the European reality. In the test, no student doubted citizens supposed quality of life in the protected natural spaces of Europe, a circumstance that corroborated the need to experiment with the reflexive and critical geography. 
Thus, the research began by introducing a descriptive geography, a highly correct geography to approach each of the territories under analysis. In general, students used many pictures from Google Photos to present the physical geography of the biosphere reserves, but left aside human settlements, infrastructure networks or economic activities. In other words, human geography had little presence in the students' spatial representations ${ }^{3}$ of natural spaces. It would doubtlessly have been ideal to take the students to the biosphere reserves and see the natural elements in situ and see the influence of anthropic action on the conformation of the landscape, but, unfortunately, there were only six class sessions available for the task's completion. Under these conditions, the teaching of geography has always recognised the value of the photographs to interpret the landscape (Leif, Rustin, 1961).

The analyses related to land zoning in descriptive geography were very interesting, as they were differentiating between forest, pasture, crop or meadows, and also the uses of the soil or the distribution of the wooded masses. Another positive aspect was the use of concepts related to rural geography, urban geography and climatology, such as bocage, land consolidation, green belt, peri-urban zone, commuters or the foehn effect. The incursion of two pieces of research in cultural geography was also interestingas they made use of historical photographs from the 1956 American flight in Spain and its comparison with current satellite images taken from Google Earth. To conclude, several working groups placed value on local heritage by understanding the anthropic action as part of the landscape. Thus, the students not only referred to natural heritage, but also to historical and cultural-ethnographic.

On the contrary, descriptive geography also presented certain errors. For example, in two assignments the cartography was poorly selected and out of date maps were introduced, others made errors with toponymy and there were also some that offered outdated information by not resorting to official sources.

The introduction of descriptive geography gave way to an active geography embodied in quantitative analyses and representations in the form of maps, tables and graphs. Statistical analyses taken from official sources on the Internet were very positive. Tables contrasting local statistics with regional, national and $\mathrm{Eu}-$ ropean data were very interesting. Moreover, the students started the work with statistical bases and were able to verify the difficulties presented by the analy-

From here on, a very interesting line of research related to the geography of perception and behaviour is opened because all geographic knowledge is based on a series of representations that allow the discovery ofhow individuals and communities see and feel about the space (Rodríguez Lestegás, 200o). sis with sources from other countries or supranational, as has happened with the use of Portuguese INE and Eurostat. It was surprising to see that the students did not limit themselves to presenting bar graphs, columns or sectors, butmade use of bar graphs or stacked columns, combined lines with columns or population pyramids. In short, a whole series of graphical solutions were used to show statistical information in a more comprehensive way.

Some research used chorochromatic cartography or figures to cross variables with larger territorial entities; an exercise that fits in with comparative geography and one which requires a greater effort from the students. Previously, several working groups had also been able to interpret the correlations between population and economic variables through the use of maps. Thus, for example, the students understood the population problem in rural areas, offered solutions for agriculture, or for related environmental conditions undergoing population dispersion throughout the territory.

At this point, it is worth remembering the significance of cartography as a strategic tool in geographic education. If we focus on the presence of cartographic documents in textbooks, apart from the fact that many topographic and thematic maps only offer a merely illustrative function, the proposed learning activities to work with these resources do not require, in most cases, the document to be seen, it is merely enough to collect the requested information directly from the accompanying text or, at the most, to carry out some verification in relation to its mapped location. To this should be added the numerous activities that refer to the use of mute maps for the sole purpose of locating and naming certain geographic points, whether they be countries, cities, mountains, rivers or any other place mentioned in the corresponding lesson (Rodríguez Lestegás, 2003). Nevertheless, and this was one of the pretensions pursued in the research, it is possible to use the cartographic documents in the classroom by putting them at the service of a school geography that, starting from a problematisation of the contents, focuses on nothing more and nothing less than that of geographically educating the citizens.

Beyond cartographic analysis, active geography also had some deficiencies. A common error was the representation of bar graphs starting from values greater than zero at the origin, that is, at the crossing of the ordinates axis with the abscissa there were different starting amounts, always above zero, so this made it difficult to compare the graphs. Also, when using some tables they did not know how to identify the variables in certain columns and made use of inappropriate titles, or they used absolute values when it 
would have been better to work with percentage values.

All this previous construction led to the definitive step towards reflective and critical geography, not only referring to sustainable development in natural spaces, but also in relation to other human geography issues. For example, the students questioned Galicia's territorial structure because they understood that it is not sustainable to maintain municipalities with populations below 1,00o inhabitants. They also criticised the low population densities in many European Union territories and highlighted the need for European research at NUTS 4 level, that is, with territorial entities below the provincial scale (in Galicia they would correspond with the regions). They even came to theorise the concept of quality of life by questioning the most commonly used indicators to quantify it objectively.

In conclusion, all works questioned the quality of life in the spaces analysed. Only one of the fifteen investigations appreciated a higher quality of life in its protected natural space than in the regional context. However, this quality of life was not associated with belonging to a specific network of natural spaces, but with the development fostered by rural tourism promotion plans.

Finally, the students criticised inappropriate territorial marketing practices, with poor public interventions that do not respond to local demands. Some research even dared to propose well-argued solutions, in the form of tourism in rural areas, recovery and enhancement of local traditions, expansion of natural and ecological agriculture or policies to attract and establish young populations. In summary, the students' research enabled a transition from an initial descriptive geography to an active, reflexive and critical one.

\section{Some reflections on theory and the conclusions}

In the teaching proposal,the intention has been to initiate the students in geographical research with a simple exercise that arouses active and reflective teaching through the use of ICT and thematic cartography. Finding, selecting and interpreting information in a critical spirit and in accordance with the needs of today's society could become a definitive strategy for school geography.

Anyhow, there is a conviction that descriptive and reflective geography no longer has a place in secondary school classrooms and, therefore, should not precisely be that geography transmitted from the university. The classroom experience has shown that the expectations and interest of students in geography grow if a different, useful and attractive geography is used. This geography can only be achieved if the students do geographic research.

It would not do any good for teachers to break away from descriptive geography if the students' activity is then limited to the simple realisation of geographical exercises (topographic cuts, population pyramids, indexes). This type of school geography was successful in the 1980s (Rio, 1981), and it is true that it is still very present in the official curricula, and also in the manuals, but it is a geography that leads to nothing; it is a geography that Souto (1998) and Bale (2014) defined in their day as active, referring to a way of doing geography in which the students receive all the facilities (technical explanations, examples and information) and then repeat previous geographic exercises proposed by teachers. For example, a teacher explains how a climograph is carried out and then asks the students themselves to design another one based on data in the form of temperatures and precipitations that are also provided by the teacher. The students, no doubt, learn the technique to carry out climographs, but they will not gather the necessary skills to do them in other conditions.

Active geography, as opposed to the activist, prepares students to do geography. They will be responsible for arriving at the information because they will know the sources and they will gather the necessary competences to arrive at them. And once located they will know how to deal with the data, make comparisons, evolutions, projections. In other words, they will be competent in doing geography without the permanent help of the teacher.

At this point one wonders why active geography is given so much value. Is it really necessary for students to do geography? Traditionally geography as a science is built in the university and part of that knowledge, in an adapted way, reaches the education classroom (Chevallard, 2000). So where are the advantages of school research? The answer is apparently simple. School research arouses students' interest in geography (Souto, 2013). Understanding the territorial realities through research leads to a breakaway from descriptive geography, and this will, in turn, lead to the moment when students no longer see geography as a dull discipline that brings nothing but general knowledge.

The idea is to present the problems in society on a territorial basis within the classroom, problems that students must identify, seek and select information for, analyse, interpret and offer solutions. Research thus becomes the answer to a problem and that response will often be multiple and will generate doubts, debate, critical reflection and ultimately the participation of all (Benejam, 1996). At that point we will be able to talk about a different geography, a useful geog- 
raphy as a science and as a school discipline. And we will also be able to speak of competent students who generate geographical knowledge, issue well-argued opinions, question official speeches, condemn social injustices. In short, geography as a school discipline will work towards strengthening students' social and civic competence.

\section{Acknowledgements}

This research has received funding from the Programme for Research, Development and Technological Innovation oriented to the Challenges of Society (CSO201675236-C2-1-R) and the National Plan of ReD from the Spanish Government (EDU2015-65621-C3-1-R) co-financed with ERDF funds from the European Union.

\section{References}

Armas Quintá, F. X., Macía Arce, X. C. 2014. Atlas A Sociedade da Información en Galicia. Manual de cartografía para a aprendizaxe, ensinanza e xestión do territorio. Andavira, Santiago de Compostela, 371 pp. (in Galician)

Bale, J. 2014. Geography in the Primary School. Routledge, New York, 182 pp.

Benejam, P. 1996. La Didáctica de la Geografía en el contexto del pensamiento de finales del siglo XX. La influencia del postmodernismo. IBBER, Didáctica de las Ciencias Sociales, Geografía, e Historia 9, 7-14. (in Spanish)

Chevallard, Y. 200o. La transposición didáctica. Del saber sabio al saber enseñado. Aique, Buenos Aires, 196 pp. (in Spanish)

ESPON. 2013. ESPON ATLAS Territorial Dimensions of the Europe 2020 Strategy. ESPON Coordination Unit, EuropeanUnion, Luxembourg, 125 pp.

Gil Saura, E. 1994. Un ejemplo de uso de la asociación de palabras como técnica de recogida de datos sobre la representación del mundo social: la reconstrucción del campo semántico de los alumnos acerca del tema del Tercer Mundo. Didáctica de las Ciencias Experimentales y Sociales 8, 27-51. (in Spanish with English summary)

Leif, J., Rustin, G. 1961. Didáctica de la Historia y de la Geografía. Kapelusz, Buenos Aires, 142 pp. (in Spanish)

Liu, H. J., Hilton, D., Huang, L., Gastardo-Conaco, C., Dresler-Hawke, E., Pittolo, F., Hong, Y., Ward, C., Abraham, S., Kashima, Y., Kashima, E., Ohashi, M. M., Yuki, M., Hidaka, Y. 2005. Social representations of events and people in world history across 12 cultures. Journal of cross-cultural psychology 362, 1-21.
Lois, R. C., Macía, X. C., Paül, V. 2013. A composite index to measure the achievement of the "Europe 2020 Strategy" by regions and member states: how far are territories to emerge from the crisis? In: Holstein, F., Zillmer, S., Böhme, K. [eds.]. Science in support of European Territorial Development and Cohesion. Second ESPON 2013 Scientific Report. ESPON Coordination Unit, Luxembourg, pp. 22-26

Luis Gómez, A. 1985. La geografía en el bachillerato español (1836-1970). Universitat, Barcelona, 349 pp. (in Spanish)

Macía Arce, X. C., Rodríguez Lestegás, F., Armas Quintá, F. X. 2016. Atlas da Sociedade da Información en Galicia: a cartografía temática como recurso didáctico. Revista Galega de Educación 65, 80-83. (in Galician)

Macía Arce, X. C., Rodríguez Lestegás, F. y Armas Quintá, F. X. 2016. La cartografía temática como recurso didáctico en los procesos de enseñanza y aprendizaje de las ciencias sociales para educación primaria. Revista Brasileira de Educação em Geografia 6-12, 428-438. (in Portuguese)

Macía Arce, X. C., Rodríguez Lestegás, F., Armas Quintá, F. X. 2015. Manual de aprendizaxe e ensinanza de Xeografía e Ciencias Sociais para Educación Secundaria. Andavira, Santiago de Compostela, 168 pp. (in Galician)

Macía Arce, X. C. 2013. La cartografía regional de la Unión Europea como recurso didáctico para las aulas de geografía. ÍBER Didáctica de las Ciencias Sociales, Geografía e Historia 74, 37-42. (in Spanish)

Río Barxa, F. X. 1981. Didáctica da Xeografía. Galaxia, Vigo, 120 pp. (in Galician)

Rodríguez Lestegás, F. 2003. Los documentos cartográficos como ejercicios-tipo para el control del conocimiento geográfico escolar. Boletín de la Asociación de Geógrafos Españoles 35, 263-271. (in Spanish with English summary)

Rodríguez Lestegás, F. 2000. Viejas y nuevas geografías, viejas y nuevas propuestas didácticas. El fin de los exclusivismos. Boletín de la Asociación de Geógrafos Españoles 29, 93-108. (in Spanish with English summary)

Souto González, X. M. 2013. Investigación e innovación educativa: el caso de la geografía escolar. Scripta Nova. Revista Electrónica de Geografía y Ciencias Sociales 18. (in Spanish with English summary)

Souto González, X. M. 1998. Didáctica de la Geografía: problemas sociales y conocimiento del medio. Ediciones del Serbal, Barcelona, 397 pp. (in Spanish)

\section{Other sources}

Internet: Eurostat. http://ec.europa.eu/eurostat 